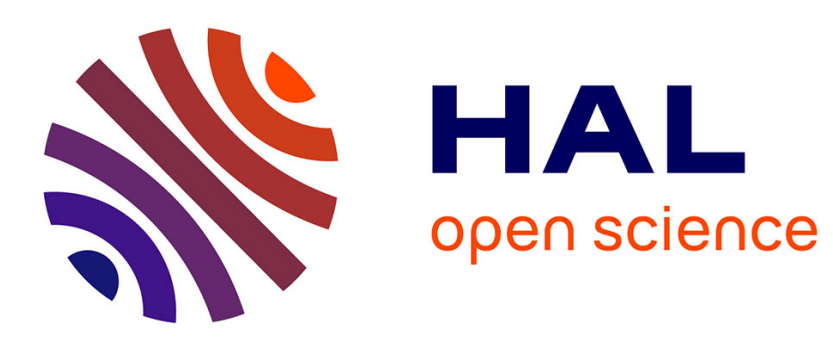

\title{
Compliance and Implementation
}

Sandrine Maljean-Dubois

\section{To cite this version:}

Sandrine Maljean-Dubois. Compliance and Implementation. Companion to Global Environmental

Governance, 2020. halshs-02926756

\section{HAL Id: halshs-02926756 \\ https://shs.hal.science/halshs-02926756}

Submitted on 2 Sep 2020

HAL is a multi-disciplinary open access archive for the deposit and dissemination of scientific research documents, whether they are published or not. The documents may come from teaching and research institutions in France or abroad, or from public or private research centers.
L'archive ouverte pluridisciplinaire HAL, est destinée au dépôt et à la diffusion de documents scientifiques de niveau recherche, publiés ou non, émanant des établissements d'enseignement et de recherche français ou étrangers, des laboratoires publics ou privés. 
Companion to Global Environmental Governance, A. Orsini et J.-F. Morin ed., Routledge/Earthscan, 2020

\title{
Chapter 16: Compliance and implementation
}

\author{
Sandrine Maljean-Dubois \\ Aix Marseille Univ, Université de Toulon, Univ Pau \& Pays Adour, CNRS, DICE, Aix-en-Provence, \\ France
}

Since the 1990s and after two decades of abundant law-making activities, scholars and practitioners are still searching for ways and means to improve the effectiveness of international environmental law, in particular that of treaty-based obligations. Indeed, the implementation of international law suffers from longstanding difficulties, implementation being understood as measures-legislative, administrative, or judicial-that parties take so as to make international agreements operative in international and domestic law (Young 1999).

The lack of implementation comes from various factors, including the softness of international obligations in this field (often vague, indeterminate, open-textured, non-quantified, and non-self-executing) or the specificities of environmental harm. It can also come from the fact that states have no or little available capacity to meet the various requirements imposed by international environmental law.

Traditional means of response to violations of international obligations do not fit to the needs in the environmental field, and even though international dispute resolution mechanisms are developing, it is still exceptional and in several respects poorly tailored to control compliance to obligations arising from multilateral treaties. Similarly, countermeasures are not particularly suited for environmental protection because states' obligations are non-reciprocal and based on a collective and superior interest.

One of the ways to address these difficulties and enhance the protection of the environment is to improve the monitoring and response mechanisms to non-compliance (Sand 1992). Such monitoring has to be tailored to the numerous peculiarities of this specific field of international cooperation. In the eyes of the common interest pursued by all Contracting Parties, it is more appropriate to financially or technically assist the state in difficulties than to ask for state liability (Chayes and Chayes 1995). In most cases, cooperation and assistance will fruitfully replace sanction. With a view to promoting the treaty implementation, some means for remedy are proposed to the states, along with possible legal, technical, and financial assistances if necessary. Some believe it is more important to promote compliance than to punish non-compliance, especially as the use of sanctions would discourage states' participation and thus encourage free riding.

All these factors prompted efforts to find alternative ways of settling disputes with an essentially preventive vocation and to the introduction of innovative international monitoring procedures inspired in part by tried and tested methods in other legal fields (such as disarmament or human rights). Since the 1990s, several environmental agreements have succeeded in reinventing themselves, and completed reporting and other monitoring methods (monitoring networks, inquiries) with more specific, ambitious, global, and coherent mechanisms to institutionalize monitoring and response to non-compliance. 
In most cases, a compliance committee is established by the Conference of Parties, which specifies its composition, mandate, decision-making powers, rules of procedure, and its relationship to other bodies. Most of these committees are designed to prevent non-compliance and facilitate compliance. When non-compliance is found, they can help non-compliance states to return to compliance, for example using technology transfer or capacity building assistance. They can also sanction non-compliance and settle disputes. In such cases, monitoring and control are no longer bilateral and reciprocal but multilateral and centralized, placed in the hands of treaty bodies (Conferences of Parties, subsidiary organs, and secretariats) as a response to non-compliance, which includes assistance and incentives in addition to actual sanctions (carrots and sticks). Collective measures appear to be more readily adopted, better tolerated and, in principle, less discretionary. Procedures are implemented with flexibility, using soft enforcement and generally a non-adversarial approach. Although in theory the different stages of the compliance-control cycle can be distinguished, in practice the boundaries between these stages are porous, and a situation can trigger the whole extent of compliance-control procedures and stages, from facilitation to enforcement. Non-compliance mechanisms are alternatives to traditional Dispute Resolution Mechanisms but they leave them untouched. Consequently, dispute resolution mechanisms can - at least in theory-complement non-compliance ones in certain cases. Finally, these procedures are used for assessing the effectiveness of states' obligations as well as clarifying and developing these obligations. They also foster collective "learning by doing" and increase transparency, which in turn builds confidence and limits free riding (Brown Weiss and Jacobson 1998; Maljean-Dubois and Rajamani 2011).

The first non-compliance procedure of an environmental treaty was drawn up in 1990 in the framework of the Montreal Protocol of the ozone regime. This pioneering procedure has already been taken up and adapted by fifteen other environmental conventions, becoming little by little a standard practice. Although inspired by the same model, all these procedures have peculiarities of their own.

The Kyoto Protocol of the climate change regime has for instance given rise to the most comprehensive non-compliance procedure to date. The monitoring and control procedure was very coherent and intrusive. Divided into two branches, a facilitative branch and an enforcement one, the Compliance Committee was quasi-judicial. Potential sanctions were essentially intended to be dissuasive. This procedure has been replaced by a more flexible one within the Paris Agreement (2015), combining an individual monitoring (the "transparency framework"), a collective assessment (the "global stocktake") and a soft compliance mechanism (the "mechanism to facilitate implementation of and promote compliance").

The non-compliance mechanism of the Aarhus Convention on Access to Information, Public Participation in Decision-Making and Access to Justice in Environmental Matters (1998) provides another remarkable example because of the powers the public is granted under the Compliance Committee's procedure. It may be triggered by a party making a submission on compliance by another party, a party making a submission concerning its own compliance, a referral by the secretariat and, something that remains most unusual in non-compliance mechanisms, by members of the public who can submit communications concerning a party's compliance with the Convention. In practice, this is by far the most used and it greatly improves participation (Treves 2009).

\section{References}

Brown Weiss, Edith and Harold K. Jacobson. 1998. Engaging Countries: Strengthening

Compliance with International Environmental Accords. Cambridge, MA, MIT Press. 
Chayes, Abram and Antonia H. Chayes. 1995. The New Sovereignty: Compliance with Treaties in International Regulatory Regimes. Cambridge, MA, Harvard University Press.

Hedemann-Robinson, Martin. 2018. Enforcement of International Environmental Law: Challenges and Responses at the International Level. London, Routledge.

Maljean-Dubois, Sandrine and Lavanya Rajamani (Eds.). 2011. Implementation of International Environmental Law. The Hague Academy of International Law, Martinus Nijhoff.

Sand, Peter. 1992. The Effectiveness of International Environmental Law: A Survey of Existing Legal Instruments. Cambridge, Grotius Publications.

Treves, Tullio (Ed.). 2009. Non-Compliance Procedures and Mechanisms and the Effectiveness of International Environmental Agreements. The Hague, Asser Press.

Young, Oran. 1999. The Effectiveness of International Environmental Regimes: Causal Connections and Behavioral Mechanisms. Cambridge, MA, MIT Press. 